\title{
Preparation and in vitro characterization of etofenamate emulgels using quality by design
}

\author{
Gülşen YILMAZ 1 (D), Sakine TUNCAY TANRIVERDi் 2 * (D), Buket AKSU 3 (D), Gizem YEĞEN 3 (D), \\ Özgen ÖZER ${ }^{2}$
}

1 Turkish Medicines and Medical Devices Agency, Quality Department, Ankara, Turkey.

2 Ege University, Faculty of Pharmacy, Department of Pharmaceutical Technology, İzmir, Turkey.

3 Altınbaş University, Faculty of Pharmacy, Department of Pharmaceutical Technology, İstanbul, Turkey.

Corresponding author. E-mail: sakinetuncay@windowslive.com (S.T.T.); Tel: +90 232-311 3981.

Received: 04 October 2018 / Revised: 22 July 2019 / Accepted: 01 August 2019

\begin{abstract}
Quality by Design (QbD) emerged with quality guidelines issued by the International Council on Harmonization ( $\mathrm{ICH})$; is a concept that suggests the quality of product cannot be secured by the finish product tests; product quality should be ensured by starting from risk and scientific based work in process and product development through the whole product life cycle. Statistical studies, which are done by computer program, have important role in today's pharmaceutical area. ANN (Artificial Neural Network) and GEP (Gene Expression Programming) are modelling techniques can be used for analyzing big amount of data, in understanding the relations between dependent and independent variables affecting product quality and optimizing the formulation variables and process parameters to get the desired product quality continuously. In this study, different etofenamate emulgel formulations were prepared, the quality characteristics determined to be critical were evaluated separately with the ANN, and GEP modeling techniques for the optimization of the formulations examined. During the modeling, the input values were oil type, oil ratio and polymer ratio and the outputs were $\mathrm{pH}$, conductivity, viscosity and flow properties of the emulgels. According to results of pre-formulation studies both of the programs suggested two optimized formulations. Depending on the further studies, the viscosity and rheological behavior showed that both formulations were could apply on skin.
\end{abstract}

KEYWORDS: Quality by design; etofenamate; artificial neural networks (ANNs); gene expression programming (GEP); emulgel.

\section{INTRODUCTION}

Quality by Design $(\mathrm{QbD})$ is a concept that suggests the quality should not only be tested on the finish product; product quality should be ensured in formulation and process development stages, which are more robust and reliable when done by following QbD steps. While this concept established with quality guidelines of International Council on Harmonization (ICH) other approaches like risk assessment, mathematical modelling and optimization were recommended as helpful to determine critical attributes and parameters, also, create design space [1,2]. ANN (Artificial Neural Network) and GEP (Gene Expression Programming) are modelling techniques can be used for analyzing big amount of data, modelling the relations between dependent and independent variables affecting product quality and optimizing the formulation variables and process parameters to get the desired product quality continuously [3].

Etofenomate is a non-steroidal anti-inflammatory drug. Several preparations of etofenomate are available in the market as different topical preparations [4]. In spite of many advantages of gels used for topical delivery, a major limitation is in the delivery of hydrophobic drugs. Therefore, to overcome this limitation, emulgels are prepared and used for hydrophobic drugs [5, 6]. Emulgel formulations are using for topical delivery of both hydrophilic and hydrophobic drugs. They have many favorable properties such as being thixotropic, greaseless, easily spreadable, easily removable, emollient, non-staining, long shelf life, biofriendly, transparent and pleasing appearance $[7,8]$. In this study, QbD was used to optimize emulgel formulation of etofenamate for the first time. Different etofenamate emulgel formulations were prepared by using two types of oil with two ratios and different concentration of Carbopol ${ }^{\circledR} 940$ [9]. The formulations were characterized via several parameters such as $\mathrm{pH}$, conductivity, viscosity and flow properties [10].

How to cite this article: Yılmaz G, Tanrıverdi Tuncay S, Aksu B, Yeğen G, Özer O. Preparation and in vitro characterization of etofenamate emulgels using quality by design. J Res Pharm. 2019; 23(6): 1033-1039. 


\section{RESULTS}

\subsection{Pre-formulation studies}

The composition of emulgel formulation was given in Table 1 . The hydrogel part of formulations was prepared with $0.125,0.25$ and $0.625 \%$ of polymer. The liquid paraffin or oleic acid was used for the part of oil phase of system. 12 emulgel formulations were prepared as shown in Table 2.

Table 1. The composition of emulgel formulations.

\begin{tabular}{lll}
\hline & Content & Amount (g) \\
\hline Hydrogel & Distilled water & $16.15 / 13.65$ \\
& EDTA & 0.025 \\
& Carbopol $^{\circledR} 940$ & $0.125 / 0.25 / 0.625$ \\
& Triethanolamine & 0.125 \\
& Tween 80 & 1.25 \\
\hline Oil Phase & Lipex Shea & 0.125 \\
& Phenoxyethanol capp. & 0.125 \\
& Transcutol ${ }^{\circledR} \mathrm{P}$ & 1.2 \\
& Propylene glycol & 0.75 \\
& Liquid paraffin/Oleic Acid & $5 / 7.5$ \\
\hline Active Ingredient & Etofenamate & 1.25 \\
\hline
\end{tabular}

Table 2. The composition of emulgel formulations with different amount of oil and polymer amount.

\begin{tabular}{lllcc}
\hline Codes & Formulation Codes & Oil Type & Oil Ratio (\%) & Polymer Ratio (\%) \\
\hline F1 & F1-1 & LP* & 20 & 0.5 \\
F2 & F2-1 & LP & 20 & 1 \\
F3 & F3-1 & LP & 20 & 0.25 \\
F4 & F1-2 & LP & 30 & 0.5 \\
F5 & F2-2 & LP & 30 & 1 \\
F6 & F3-2 & LP & 30 & 0.25 \\
F7 & F1-3 & OA* & 20 & 0.5 \\
F8 & F2-3 & OA & 20 & 1 \\
F9 & F3-3 & OA & 20 & 0.25 \\
F10 & F1-4 & OA & 30 & 0.5 \\
F11 & F2-4 & OA & 30 & 1 \\
F12 & F3-4 & OA & 30 & 0.25 \\
\hline *LP is liquid paraffin; OA is oleic acid. & & &
\end{tabular}

\subsection{Characterization of formulations}

The characterization studies of the formulations showed that the viscosity, $\mathrm{pH}$ and conductivity changed due to the composition. All formulations have non-newtonian behavior and pseudoplastic flow. The viscosity and rheological behavior showed that both formulations could be applied on skin. The $\mathrm{pH}$ of formulations was between 5.5 and 7.5 that are acceptable for topical application on skin. The viscosity, $\mathrm{pH}$ and electrical conductivity results of formulations were shown in Table 3 and Figure 1. 
Table 3. The characterization results of formulations.

\begin{tabular}{lllll}
\hline Codes & Macroscopic observation & Viscosity (Pas) & pH & $\begin{array}{l}\text { Conductivity } \\
(\boldsymbol{\mu S}-/ \mathbf{c m})\end{array}$ \\
\hline F1 & White, homogeneous & 10.55 & 7.41 & 430 \\
F2 & White & 25.66 & 5.75 & 465 \\
F3 & White, homogeneous & 4.30 & 7.41 & 205 \\
F4 & White, homogeneous & 13.6 & 6.8 & 270 \\
F5 & White & 29.8 & 5.3 & 280 \\
F6 & White, homogeneous & 6.23 & 7.71 & 165 \\
F7 & White, homogeneous & 8.91 & 5.75 & 520 \\
F8 & White & 4.04 & 5.8 & 634 \\
F9 & White, homogeneous & 5.61 & 6.45 & 444 \\
F10 & White, homogeneous & 2.4 & 5.8 & 396 \\
F11 & White & 6.60 & 5.5 & 460 \\
F12 & White, homogeneous & 9.99 & 6.49 & 430 \\
\hline
\end{tabular}

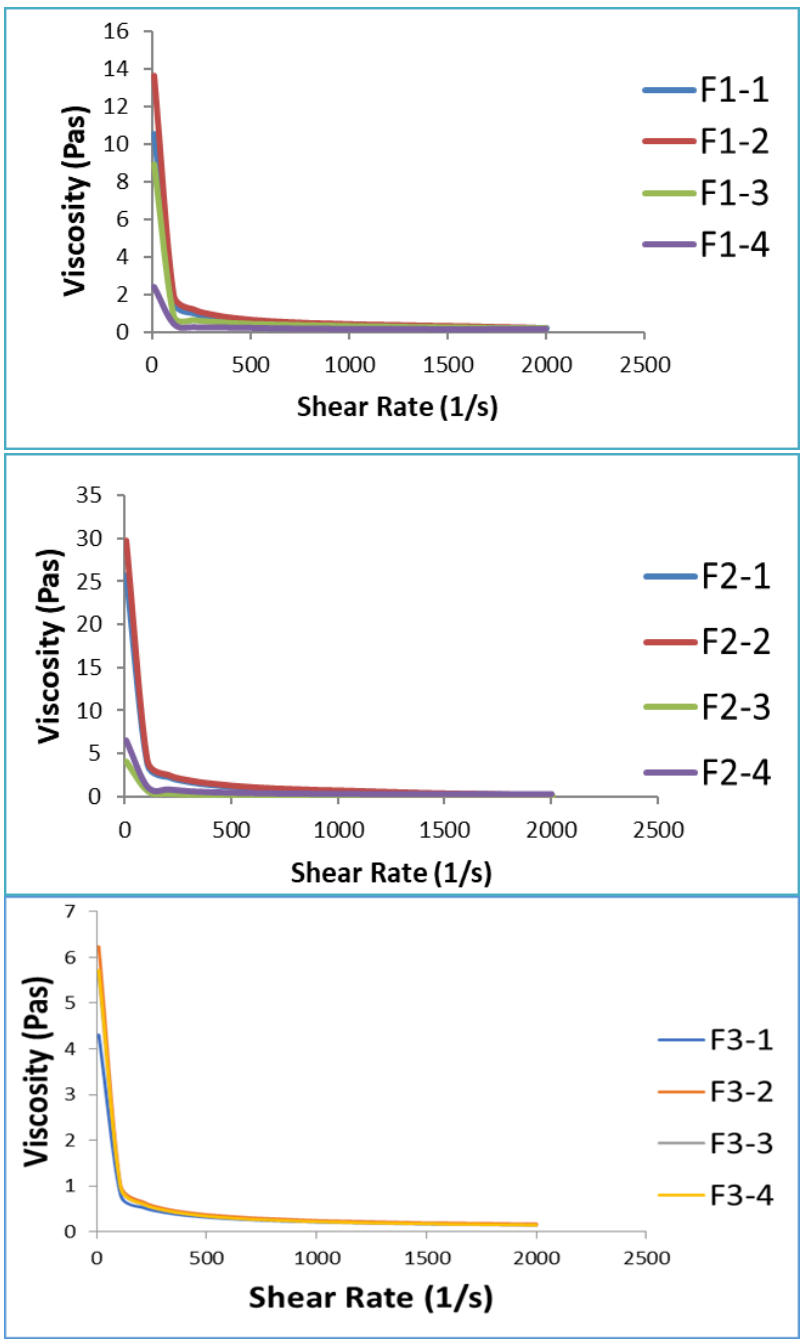

Figure 1. The graphs of viscosity versus shear rate. 


\section{DISCUSSION}

\subsection{Characterization of formulations}

For the formulation prepared with liquid paraffin, viscosity increased with increasing polymer concentration as expected from pseudoplastic gels. However, for oleic acid formulations, the viscosity did not change with increasing polymer concentration. The result shows that oil type is an important parameter on viscosity of formulations. The $\mathrm{pH}$ of the formulations should be around skin $\mathrm{pH}(5.5)$ or neutral $\mathrm{pH}(7)$. The results show that the $\mathrm{pH}$ of formulations between skin $\mathrm{pH}$ and neutral $\mathrm{pH}$ which is appropriate for topical application of formulations. The results showed that $\mathrm{pH}$ is differed with the composition. The electrical conductivity is a parameter, which is tested during stability studies to show chemical stability. It was seen that conductivity was increased when polymer concentration was higher and the higher conductivity values were observed with the oleic acid formulations.

\subsection{Optimization studies}

Training result of the model is given at Table 4; and according to $\mathrm{R}^{2}$ and f-ratio values, a robust model were obtained for all outputs. Both programs showed nearly same composition for the optimum formulation as shown in Table 5. The optimized formula given by ANN modelling (F1) was oil type 1 which is liquid paraffin, oil ratio $20.83 \%$, polymer ratio 0.57 ; optimized formula given by GEP modelling (F2) was oil type 1 again, oil ratio $20 \%$, and polymer ratio 0.71 (Table 6 ).

Table 4. Training results of specifications for each model.

\begin{tabular}{lcccc}
\hline & \multicolumn{2}{c}{ ANN } & \multicolumn{2}{c}{ GEP } \\
\cline { 2 - 5 } Specifications & $\boldsymbol{R}^{\mathbf{2}}(\boldsymbol{\%})$ & f-Ratio & $\boldsymbol{R}^{\mathbf{2}} \mathbf{( \% )}$ & $f$-Ratio \\
\hline $\mathrm{pH}$ & 97.52 & -17.03 & 90.69 & -6.75 \\
Conductivity & 97.84 & -19.37 & 95.57 & -14.79 \\
Viscosity & 96.93 & -13.81 & 97.71 & -30.39 \\
Flow & 97.95 & -8.71 & 98.56 & -50.51 \\
\hline
\end{tabular}

Table 5. The composition of formulations that obtained by ANN and GEP.

\begin{tabular}{lccc}
\hline & Composition & ANN & GEP formulation \\
\hline \multirow{4}{*}{ Gel phase } & Distilled water & $64.2 \mathrm{~g}$ & $64.89 \mathrm{~g}$ \\
& EDTA & $0.1 \mathrm{~g}$ & $0.1 \mathrm{~g}$ \\
& Carbopol $^{\circledR} 940$ & $0.57 \mathrm{~g}$ & $0.71 \mathrm{~g}$ \\
& Triethanolamine $^{*}$ & $0.5 \mathrm{~g}$ & $0.5 \mathrm{~g}$ \\
\cline { 2 - 4 } Oil phase & Tween 80 & $5 \mathrm{~g}$ & $5 \mathrm{~g}$ \\
\cline { 2 - 4 } & Lipex Shea & $0.5 \mathrm{~g}$ & $0.5 \mathrm{~g}$ \\
& Phenoxyethanol caprylglycol & $0.5 \mathrm{~g}$ & $0.5 \mathrm{~g}$ \\
Active ingredient & Transcutol ${ }^{\circledR} \mathrm{P}$ & $4.8 \mathrm{~g}$ & $4.8 \mathrm{~g}$ \\
& Propylene glycol & $3 \mathrm{~g}$ & $3 \mathrm{~g}$ \\
& Liquid Paraffin & $20.83 \mathrm{~g}$ & $20 \mathrm{~g}$ \\
\hline & Etofenamate & $5 \mathrm{~g}$ & $5 \mathrm{~g}$ \\
\hline
\end{tabular}

Table 6. Oil type and polymer ratio of optimized formulations via ANN and GEP.

\begin{tabular}{lll}
\hline Composition & Optimum Formula by ANN & Optimum formula by GEP \\
\hline Oil type & 1 & 1 \\
Oil ratio & $20.83 \mathrm{mg}$ & $20 \mathrm{mg}$ \\
Polymer ratio & $0.57 \mathrm{mg}$ & $0.71 \mathrm{mg}$ \\
\hline
\end{tabular}

\subsection{Preparation of optimum formulations}

The optimum formulations that specified by modelling programs were prepared and characterized by parameters as mentioned above. The $\mathrm{pH}$ of formulations were 5.76 (F1) and 5.94 (F2). Electrical conductivities were found 298 (F1) and 262 (F2) $\mu$ S-1. The viscosity and rheological behavior (Figure 2) showed that both formulations could be applied on skin. 


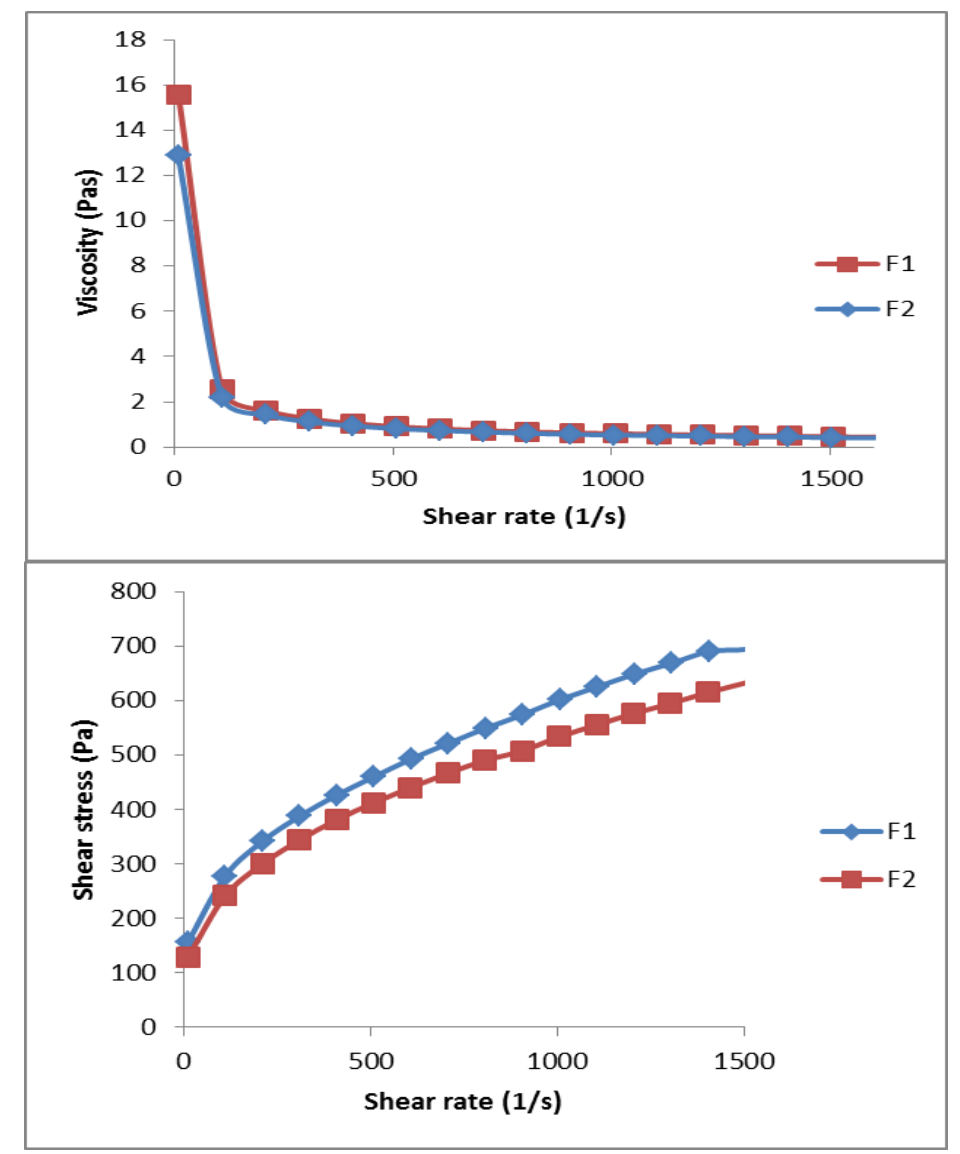

Figure 2. The viscosity and rheology graph of optimum formulations.

\section{CONCLUSION}

With this study, QbD approach and artificial intelligence modelling techniques were used to develop an etofenamate emulgel formulation for topical delivery, for the first time. Because of overall studies, an efficient formula, which can be applied topically, was obtained via mathematical modelling techniques. Even though there are few formulations appropriate for the topical delivery were obtained from the studies, the formulations show ideal rheological behavior and viscosity were formed by computer software. Especially, in the way input and output values modelling programs suggested different formulations, which were not evaluated in pre-formulation studies and the attributes of these formulations, were found proper. The results showed that both programs could be used to establish optimum formulation and these could be very helpful for research studies in universities and in industry as time and money savers.

\section{MATERIALS AND METHODS}

\subsection{Materials}

Etofenamate was a kindly gift from Union Quimico Farmaceutica, S.A.(Spain), Tween 80, triethanolamine, liquid paraffin and oleic acid was obtained from Merck KGaA (Germany). EDTA, Carbopol ${ }^{\circledR}$ 940 and lipex shea were purchased from Kale Kimya (Turkey), Corel Pharma Chem. (India) and AAK company (Sweeden), respectively. Phenoxyyethanol capryl glycol, Transcutol ${ }^{\circledR} \mathrm{P}$ and propylene glycol were provided from Verstatil PC (Germany), Gattefosse (France) and Sigma Aldrich (USA), respectively. Deionized (DI) water was obtained from ultrapure water system (Model-Arium 611) of Sartorius AG (Germany).

\subsection{Pre-formulation studies of emulgel formulations}

Pre-formulation studies of etofenamate emulgels were performed to apply QbD and find optimum composition of etofenamate emulgel formulation. According to the compositions are given in Table 1 etofenamate emulgel formulations were prepared. 
Firstly, EDTA was dissolved in distilled water and Carbopol ${ }^{\circledR} 940$ was added to solution. Tween 80 as mixed with while the system was mixing under magnetic stirrer. Then, triethanolamine was added to obtain optimum $\mathrm{pH}$ for jellifying of polymer. Two types of oil (liquid paraffin and oleic acid) with two ratios were used for preparation of emulsion phase. The oil phase was composed of oil, shea butter, phenoxyethanol capryl glycol, Transcutol ${ }^{\circledR} \mathrm{P}$ and propylene glycol. Then, etofonamate was added to oil mixture. As last step, oil phase was added to gel phase by drop by drop while the system is mixing under mechanic stirrer at 1000 rpm for $15 \mathrm{~min}$.

\subsection{Characterization of formulations}

The formulations were characterized via macroscopic evaluation, $\mathrm{pH}$, conductivity, viscosity and flow properties. The color, viscosity and phase separation of formulations were evaluated macroscopically. The $\mathrm{pH}$ values of the formulations were determined by using a $\mathrm{pH}$ meter (Jenway 3040 Ion Analyze, Staffordshire, UK) at $25 \pm 1^{\circ} \mathrm{C}$. All experiments were replicated at least three times. Conductivity of formulations was measured by using a conductivity meter (Jenway, 4071 , Staffordshire, UK) at $25 \pm 1^{\circ} \mathrm{C}$.

The rheological analysis of the formulations was performed at $20 \pm 0.1^{\circ} \mathrm{C}$ using an AR 2000 controlled stress/controlled rate rheometer (Haake MARS, plate PP35 Ti, plate cover MPC35, Karlsruhe, Germany). The plate / plate system $60 \mathrm{~mm}$ diameter and 1 degrees angled with gap $0.3 \mathrm{~mm}$ was used. In continuous shear analysis, the upward and downward flow curves for each formulation were measured over shear rates ranging from 10 to $900 \mathrm{~s}^{-1}[11,12]$.

\subsection{Optimization studies}

ANN and GEP modelling systems were applied to experimental data to obtain a recommended optimized emulgel formulation and to enlighten the relationship between independent input variables and the CQAs. Oil type, oil ratio and polymer ratio were determined as inputs and $\mathrm{pH}$, conductivity, viscosity, flow were determined as outputs. Liquid paraffin (oil type 1) and oleic acid (oil type 2) were used as oil phase in the range of $20 \%$ or $30 \%$. The concentrations of polymer (Carbopol ${ }^{\circledR} 940$ ) were changed as $0.25,0.5$ and $1 \%$. Two different formulations obtained from ANN and GEP models with appropriate training results (ANOVA statistics). After models were created, two optimum formulations were recommended. Experimental studies further conducted on the optimized formulations [13, 14].

\subsection{Preparation of optimum formulations}

The optimum formulations were selected with ANN and GEP models. Two formulations were prepared as mentioned in Section 5.1. The formulations were characterized via parameters such as $\mathrm{pH}$, electrical conductivity, macroscopic observation, viscosity and rheological analysis. Table 6 shows the oil phase and composition of optimum formulations selected by two models.

Acknowledgements: The authors would like to thank Ege University, Faculty of Pharmacy, Pharmaceutical Sciences Research Center (FABAL) for rheological analysis facilities.

Author contributions: Concept - G.Y, S.T.T., B.A., G.Y., Ö.Ö.; Design - G.Y, S.T.T., B.A., G.Y., Ö.Ö.; Supervision - G.Y, S.T.T., B.A., G.Y., Ö.Ö.; Resources - G.Y, S.T.T., B.A. Ö.Ö.; Materials - G.Y, S.T.T., B.A.; Data Collection and/or Processing - G.Y, S.T.T., B.A., G.Y., Ö.Ö.; Analysis and/or Interpretation - G.Y, S.T.T., B.A., G.Y., Ö.Ö.; Literature Search - G.Y, S.T.T., B.A.; Writing - G.Y, S.T.T., B.A., G.Y., Ö.Ö.; Critical Reviews - G.Y, S.T.T., B.A., G.Y., Ö.Ö.

Conflict of interest statement: The authors declared no conflict of interest.

\section{REFERENCES}

[1] International Conference on Harmonisation of Technical Requirements for Registration of Pharmaceuticals for $\begin{array}{lllll}\text { Human Use } & \text { Pharmaceutical } & \text { Development } & \text { Guideline } & 2009 .\end{array}$ https://www.ich.org/fileadmin/Public_Web_Site/ICH_Products/Guidelines/Quality/Q8_R1/Step4/Q8_R2_Gui deline.pdf (accessed June 18, 2019).

[2] Pallagi E, Ambrusb R, Szabo-Reveszb P, Csoka I. Adaptation of the quality by design concept in early pharmaceutical development of an intranasal nanosized formulation. Int J Pharm. 2015; 491: 384-392. [CrossRef]

[3] Demir Ö, Aksu B, Özsoy Y. Araştırma geliştirme çalışmalarında tasarımla kalite yaklaşımı ve yapay sinir ağı modellemesinin önemi. Türkiye Klinikleri J Pharm Sci. 2015; 4(1): 17-35. [CrossRef] 
[4] Okyar A, Ozzsoy Y, Güngör S. Novel formulation approaches for dermal and transdermal delivery of non-steroidal anti-inflammatory drugs. In: Lemmey A. (Ed). Rheumatoid arthritis-treatment. Intech, Croatia, 2012, pp. 25-48. [CrossRef]

[5] Pena LE. Gel dosage forms: theory, formulation and processing. In: Osborne DW, Amann AH. (Eds). Topical drug delivery formulations. Marcel Dekker, New York, 1990, pp. 381-388.

[6] Steven P, Stanos DO. Topical agents for the management of musculoskeletal pain. J Pain Symptom Manag. 2007; 33(3): 342-355. [CrossRef]

[7] Sunil KY, Manoj KM, Anumapaa T, Ashutosh S. Emulgel a new approach for enhanced for topical drug delivery. Int J Curr Pharm Res. 2017; 9(1): 15-19. [CrossRef]

[8] Hardenia A, Jayronia S, Jain S. Emulgel: an emergent tool in topical drug delivery. Int J Pharm Sci Rev Res. 2014; 5(5): 1653-1660. [CrossRef]

[9] Jana S, Ali SA, Nayak AK, Sen KK, Basu SK. Development of topical gel containing aceclofenac-crospovidone solid dispersion by “quality by design (QbD)" approach. Chem Eng Res Des. 2014; 9(2): 2095-2105. [CrossRef]

[10] Mohamed MI. Optimization of chlorphenesin emulgel formulation. AAPS J. 2004; 6(3): 81-87. [CrossRef]

[11] Jones DS, Woolfson AD, Brown AF. Textural, viscoelastic and mucoadhesive properties of pharmaceutical gels composed of cellulose polymers. Int J Pharm. 1997; 151(2): 223-233. [CrossRef]

[12] Andrews GP, Gorman SP, Jones DS. Rheological characterization of primary and binary interactive bioadhesive gels composed of cellulose derivatives designed as ophthalmic viscosurgical devices. Biomaterials. 2015; 26(5): 571-580. [CrossRef]

[13] Aksu B, Gokce EH, Rencber S, Ozyazıcı M. Optimization of solid lipid nanoparticles using Gene Expression Programming (GEP). Lat Am J Pharm. 2014; 33(4): 675-84.

[14] Aksu B, Yegen G. Benefits of computerized technologies in pharmaceutical development with quality by design approach. J Comput Eng Inf Technol. 2017; 6(1):1-6. [CrossRef]

This is an open access article which is publicly available on our journal's website under Institutional Repository at http://dspace.marmara.edu.tr. 